Check for updates

Bogotá, Colombia

lukestephentaylor@gmail.com Cite this as: BMJ2020;370:m3088 http://dx.doi.org/10.1136/bmj.m3088 Published: 11 August 2020

\section{VIOLENCE AGAINST DOCTORS}

\section{Covid-19 misinformation sparks threats and violence against doctors in Latin America}

\section{False beliefs and decades of conflict have left Latin America's doctors facing death threats when they are already vulnerable, writes Luke Taylor}

Luke Taylor

When the 15 bed clinic managed by Diego Posada started filling in mid-June, he received an elderly patient from a nearby town with severe respiratory conditions. Owing to a lack of equipment at the small clinic in rural northwestern Colombia, he sent the patient to the capital, Bogotá, where doctors could better treat her and hopefully save her from becoming the latest victim in Colombia's losing battle against covid-19.

The patient's son did not like the decision, however. He began taking photos of Posada, his car, and its number plate. "He said that if anything happened to his mother we were responsible, that we had family and that if his mother dies, we all die," says Posada.

People later visited Posada's clinic asking for his whereabouts and issued threats against him on local radio, claiming that covid-19 did not exist and that the hospital's doctors should be killed before they could kill or kidnap patients for financial gain.

"These things are public knowledge, but we never thought they would happen to us here, and they are, constantly," he says. "It is incredibly uncomfortable and unsettling. You don't want to think about it, but it makes you think about yourself, your family, and if it's worth it doing what you do."

Already facing the emotional and physical adversities of working on the front line in the battle against covid-19, healthcare workers are being subjected to threats, violence, and intimidation from the same public they are risking their lives to treat. Such aggressions have surged around the world in recent months under the weight of the pandemic, say doctors and non-governmental organisations monitoring the crisis.

In the Philippines, a hospital utility worker was attacked on the street and had bleach poured on his face. ${ }^{1}$ In India, health workers conducting covid-19 tests were pelted with stones. In Russia, ambulance workers were attacked by a mob. Organisations monitoring these incidents say that they are hard to quantify, and most go unreported.

In May, 13 medical and humanitarian organisations-including the International Committee of the Red Cross (ICRC), the International Hospital Federation, and the World Medical Association-issued a declaration denouncing over 200 incidents of covid-19 related attacks on healthcare workers and health facilities worldwide during the pandemic. ${ }^{2}$ Yet shocking cases continue to emerge, many of which are from Latin America.

"We [watch] with great concern the increase in threats and aggressions to health personnel in Latin America," says Jose Antonio Bastos, health coordinator at ICRC Colombia. "Even in the absence of accurate data, the accumulation of social media and media information indicates that the situation of attacks on healthcare workers has worsened-both in number and nature-in Latin America since the arrival of covid-19."

\section{A history of violence}

Ramón Abel Castaño, a health consultant researching violence against doctors, says that aggressive incidents against healthcare workers have "contextual differences" in Latin America and that these differences are "particularly worrisome" in Colombia. Like Bolivia, Ecuador, and Peru, Colombia has been unable to contain the spread of covid-19 and is becoming one of Latin America's hotspots. Although lockdowns were implemented in March, the number of cases continues to increase, and intensive care units in Colombia's capital are approaching capacity.

As the strain on the healthcare system has increased, so too have reports of healthcare workers being attacked, intimidated, and evicted from their homes. ${ }^{3}$ Doctors have had faeces thrown at them by their neighbours, their hospitals have been vandalised, and they have received death threats after their patients succumbed to the illness.

One case in June-when funeral wreaths were allegedly delivered to a doctor's house after the death of one of his patients-was so shocking that Colombia's president, Ivan Duque, denounced threats against healthcare workers and pledged to bring justice to the people who made them.

Castaño says that Colombia has "a brutal history of violence. It is likely that healthcare, just [like] everyday life, is affected by that." The country's five decade civil conflict formally ended in 2016 after a peace deal with the Revolutionary Armed Forces of Colombia (FARC), a long established guerrilla army-but it has left deep scars.

A weak state and a broken "social contract" mean that people tend to take matters into their own hands or defer them to armed groups, and this also applies to grievances with health workers, Castaño believes. 
This dynamic could help explain why countries such as Mexico, where drug related violence has been rife in recent decades, have also recently faced a series of particularly appalling cases.

As of 28 April, Mexico's Ministry of the Interior had documented at least 47 cases of aggression towards health workers, ${ }^{4}$ while Mexico's National Council to Prevent Discrimination reported 265 complaints regarding discrimination on the basis of covid-19 among health workers from 19 March to 8 May. ${ }^{5}$ Mexican doctors and nurses have begun riding bicycles to work to avoid potential attacks on public transport and taxis.

In addition to the history of violence in Latin America, "there has been a loss of trust in governments and government institutions," says Castaño, who believes that this also partly explains why its doctors are less trusted and particularly vulnerable.

\section{Rumours and misinformation}

Exacerbating a regional mistrust of health workers and institutions is a wave of conspiracy theories circulating on WhatsApp and social media. Though often wild (one theory alleges that doctors are extracting a fluid from patients' knees), they are ultimately dangerous.

In May, a Colombian politician claimed that a "covid cartel” of doctors were unnecessarily admitting covid-19 patients to intensive care to receive higher payments. ${ }^{6}$ Another theory quickly spread on social media, accusing doctors of receiving a cash payment of $€ 13000$ (€14 420; \$16 975) for every dead patient with a covid-19 diagnosis.

"The government once said they were thinking of an incentive for hospitals to increase beds for covid-19 patients," says Diego Rosselli, a neurologist and epidemiologist at Bogotá's Javeriana University, who has been debunking popular misinformation in social media. "I think everything started there."

Misinformation has reportedly caused fatalities as patients avoid seeking care for fear of encountering unscrupulous doctors. ${ }^{7}$ It's also exacerbating a lack of trust in authorities, leading to threats and violence, says Rosselli.

Concerned by the wave of violence against health workers and an increase in sackings for complaining about strategies and lack of personal protective equipment (PPE), Amnesty International conducted a report on current trends and causes. It identified various structural factors, such as poor education, which makes the public more susceptible to disinformation, and a large informal economy workforce, which means that many people don't have employers to receive information and guidance from-perhaps explaining why abuse of health workers is so prevalent in Latin America. ${ }^{1}$

"A lack of education or information sees people taking responses based on fear and paranoia that turn into aggression," says Madeleine Penman, Amnesty International's researcher for the Americas.

\section{Solutions}

Some nations have taken tangible actions against abuse of health workers-Argentina's capital, Buenos Aires, is issuing fines against people who commit them-but Amnesty and the Pan American Health Organization (PAHO) are calling on governments to do more.

Marcos Espinal, director of PAHO's Department of Communicable Diseases, says that the "unbelievable" level of misinformation around covid-19 wasn't seen during the Ebola crisis of 2014, which never took root in the Americas despite fears that it would. A second reason may be the universal understanding of Ebola as a lethal disease, whereas the newness of covid-19 leaves room for misinformation.

Espinal says that solutions are within reach of governments at all levels: they can distribute simple and accessible information, and they can stop generating misinformation themselves-such as when the US president, Donald Trump, suggested using bleach to purge the virus. "The authorities need to be strong on this," says Espinal. "Healthcare workers are the backbone of the pandemic response: it's not their fault; they are people at the greatest risk."

But, with the pandemic likely to worsen in Latin America, so too could the situation for its healthcare workers as their shifts become longer and their clinics fuller. Ramón Abel Castaño predicts, "If violent manifestations are more likely to emerge in a context of tensions between family members and healthcare workers, then you can expect that they will increase in numbers and intensity during the intensive care crisis."

Competing interests: I have read and understood BMJ policy on declaration of interests and have no relevant interests to declare.

Provenance and peer review: Commissioned; not peer reviewed.

Amnesty International. Exposed, silenced, attacked: failures to protect health and essential workers during the covid-19 pandemic. 2020. https://www.amnesty.org/download/Documents/POL4025722020ENGLISH.PDF.

2 International Committee of the Red Cross. Health care workers save lives: condemnation of attacks linked to covid-19.26 May 2020. https://www.icrc.org/en/document/health-care-workerssave-lives-covid-19.

3 I lost control and started crying": Colombian doctor evicted as neighbors fear covid-19. Reuters 2020 Apr 24.

4 Government of Mexico. Observaciones sobre violaciones a derechos humanos durante la contingencia sanitaria por covid-19 [Observations on human rights violations during the health contingency by covid-19]. 2020. https:/www.gob.mx/segob/documentos/observaciones-sobreviolaciones-a-derechos-humanos-durante-la-contingencia-sanitaria-por-covid-19. (In Spanish.)

5 Trabajadores de la salud, el tercer grupo que más quejas presenta ante el Conapred [Health workers, the third group with the most complaints presented to Conapred]. La Jornada 2020 May 11. https://www.jornada.com.mx/2020/05/11/politica/005n2pol. (In Spanish.)

6 Habría cartel de la COVID-19 en las UCI en Cali? Senador denuncia [Would there be a COVID-19 poster in the ICUs in Cali?]. El Espectador 2020 May 24. https://www.elespectador.com/noticias/politica/habria-cartel-de-la-covid-19-en-las-uci-en-cali-senador-denuncia-articulo-920994/. (In Spanish.)

7 Velasquez T. El cartel del COVID y otros peligros [The COVID cartel and other dangers]. El Universal 2020 Jun 8. https://m.eluniversal.com.co/blogs/index.php/tatiana-villareal/el-cartel-del-covid-yotros-peligros. (In Spanish.)

This article is made freely available for use in accordance with BMJ's website terms and conditions for the duration of the covid-19 pandemic or until otherwise determined by BMJ. You may use, download and print the article for any lawful, non-commercial purpose (including text and data mining) provided that all copyright notices and trade marks are retained. 